\title{
Multikinase inhibitor motesanib enhances the antitumor effect of cisplatin in cisplatin-resistant human bladder cancer cells via apoptosis and the PI3K/Akt pathway
}

\author{
JIN-NYOUNG HO ${ }^{1}$, SEOK-SOO BYUN ${ }^{1}$, SANG EUN LEE ${ }^{1}$, JE-IN YOUN ${ }^{2,3}$ and SANGCHUL LEE ${ }^{1}$ \\ ${ }^{1}$ Department of Urology, Seoul National University, Bundang Hospital, Seongnam 13620; \\ ${ }^{2}$ Wide River Institute of Immunology, Seoul National University College of Medicine, Hongcheon 25159; \\ ${ }^{3}$ Department of Biomedical Sciences, Seoul National University College of Medicine, \\ Seoul 03080, Republic of Korea
}

Received August 14, 2018; Accepted January 22, 2019

DOI: 10.3892/or.2019.7005

\begin{abstract}
Motesanib (AMG 706) is a small organic molecule that acts as a multi-targeted tyrosine kinase inhibitor of VEGF, PDGF and stem cell factor receptor. It exhibits a potent antitumor effect in vitro and in vivo. To investigate the anticancer effect and possible mechanisms of motesanib in cisplatin-resistant human bladder cancer cells (T24R2), T24R2 cells were treated with motesanib $(50 \mu \mathrm{M})$ with or without cisplatin $(2.5 \mu \mathrm{g} / \mathrm{ml})$. Cell growth was assessed by the Cell Counting Kit- 8 and clonogenic assays. Cell cycle progression and apoptotic cell death were examined using flow cytometry. The expression levels of apoptosis- and survival-related proteins were determined by western blot analysis. In combination with cisplatin, motesanib exhibited synergistic inhibition on T24R2 cell growth. Treatment using motesanib in combination with cisplatin markedly induced apoptosis and promoted cell cycle arrest in the $\mathrm{S}$ phase. It also increased the expression of apoptosis-related genes including caspases, poly(ADP-ribose) polymerase and cytochrome $c$, whereas it decreased the expression of survival-related genes including p-PI3K and p-Akt. In conclusion, combination treatment with motesanib and cisplatin revealed a synergistically enhanced anticancer effect on cisplatin-resistant human bladder cancer cells, accompanied with induced apoptosis and cell cycle arrest. Thus, the multikinase inhibitor motesanib could be developed as possible therapeutic agent for bladder cancer.
\end{abstract}

Correspondence to: Professor Sangchul Lee, Department of Urology, School of Medicine, Seoul National University, Bundang Hospital, 166 Gumi-ro, Bundang-gu, Seongnam-si, Gyunggi-do 13620, Republic of Korea

E-mail: uromedi@naver.com

Key words: bladder cancer cells, motesanib, multikinase inhibitor, apoptosis

\section{Introduction}

Bladder cancer is a malignancy of the urinary tract and is the ninth most common malignancy worldwide, with an estimated 430,000 new cases, and resulting in 165,000 deaths in 2012 (1). At diagnosis, $75 \%$ of patients have non-invasive bladder cancer and $25 \%$ have muscle-invasive or metastatic disease (2). For many years, cisplatin-based combination chemotherapy, such as dose-dense methotrexate, vinblastine, doxorubicin and cisplatin (ddMVAC) or gemcitabine and cisplatin (GC) regimens, has been the standard treatment for patients with metastatic urothelial carcinoma. Although the overall response rate is $\sim 40-60 \%$, the median survival is only one year $(3,4)$. Due to drug resistance and considerable side-effects, combination therapies of cisplatin with other cancer drugs have been applied as novel therapeutic regimens for many types of cancers (5).

Angiogenesis is required for continued tumor growth, progression and metastasis of a variety of solid tumors $(6,7)$. Therefore, one of the approaches in cancer therapy has been the targeting of angiogenesis. A number of angiogenic factors are expressed in bladder cancer, including basic and acidic fibroblast growth factor (FGF), vascular endothelial growth factor (VEGF), hepatocyte growth factor, interleukin-8, and transforming growth factor- $\alpha$ (8). VEGF and its corresponding receptors (VEGFR) are the most prominent regulators of angiogenesis (6). In particular, activation of VEGFR-2 promotes the proliferation and survival of endothelial cells. VEGFR-3 appears to promote lymphangiogenesis and metastatic spread (9). The platelet-derived growth factor (PDGF) and FGF signaling pathways also control angiogenesis, tumor growth, and metastasis, and compensatory mechanisms may come into play when VEGF signaling is blocked (6). Research has revealed that both VEGFRs and the VEGF ligands are expressed in bladder cancer tissue and cells (10). Heightened levels of VEGF resulted in significantly decreased survival compared with normal levels of VEGF expression $(11,12)$.

Motesanib (AMG 706) is an orally administered, small-molecule angiogenesis inhibitor of multiple targets including VEGFR-1, -2 and -3, PDGF receptor (PDGFR), and 
stem cell factor receptor $(13,14)$. Monotherapy and combination with chemotherapy resulted in tumor regression and inhibition of angiogenesis in various xenograft models such as non-small cell lung, thyroid and colorectal cancer, and breast cancer models (9,13,15-17). Motesanib has also exhibited anticancer activity in phase 1 and/or phase 2 studies in solid tumors including ovarian, fallopian tube and primary peritoneal carcinoma, metastatic breast, thyroid and non-squamous non-small-cell lung cancer $(18,19)$.

To the best of our knowledge, the anticancer effect of motesanib on bladder cancer is still unclear. The present study was designed to investigate the efficacy of motesanib alone or in combination with cisplatin in bladder cancer cell lines and to investigate the mechanisms that mediate these effects.

\section{Materials and methods}

Cell lines and reagents. The human bladder cancer cell lines T24, 253J and HTB9 were obtained from the American Type Culture Collection (ATCC; Rockville, MD, USA). The cisplatin-resistant cell line T24R 2 was generated by serial desensitization (20). The cells were maintained in RPMI-1640 medium (Gibco; Invitrogen, Carlsbad, CA, USA) supplemented with $10 \%$ heat-inactivated fetal bovine serum and $1 \%$ penicillin/streptomycin (Gibco; Invitrogen) in a humidified atmosphere of $95 \%$ air and $5 \% \mathrm{CO}_{2}$ at $37^{\circ} \mathrm{C}$. Motesanib was purchased from Selleck Chemicals (Houston, TX, USA; Fig. 1). It was dissolved in dimethyl sulfoxide (DMSO; Sigma-Aldrich; Merck KGaA, Darmstadt, Germany) and diluted to obtain the working concentration. The final concentration of DMSO in the culture media was $0.1 \%$ (v/v). Media containing 0.1\% DMSO were used as a control. Cisplatin was obtained from JW Pharmaceutical (Seoul, Korea).

Cell viability assay. Bladder cancer cells were seeded at $2 \times 10^{3}$ in 96 -well plates. After $24 \mathrm{~h}$, the cells were incubated with motesanib, cisplatin, and a combination of the two for 48 and $72 \mathrm{~h}$. At the end of the drug exposure, $10 \mu \mathrm{l}$ of the Cell Counting Kit-8 (CCK-8) solution (Dojindo Molecular Technologies, Inc., Gaithersburg, MD, USA) was added to each well. After $4 \mathrm{~h}$ of incubation, the optical density of each well was measured at $450 \mathrm{~nm}$ using a microplate reader (Molecular Devices, LLC, Sunnyvale, CA, USA). Cell viability was calculated as the percentage of viable cells in the total population.

Synergism determination. The synergistic effect between motesanib and cisplatin was determined based on a combination index (CI) using CalcuSyn software (version 2.1; Biosoft, Cambridge, UK). The CI indicates synergism at $<1.0$, antagonism at $>1.0$, and additive effects at 1.0.

Clonogenic assays. T24 and T24R 2 cells were plated at 4x10 2 in 6-well plates, incubated with either motesanib or cisplatin, and combined for $48 \mathrm{~h}$. The cells were cultured for another 10-14 days in motesanib- and cisplatin-free medium. The colonies were fixed with methanol and stained with $0.1 \%$ crystal violet solution. The plates were photographed, and colonies $>0.2 \mathrm{~mm}$ in diameter were counted.

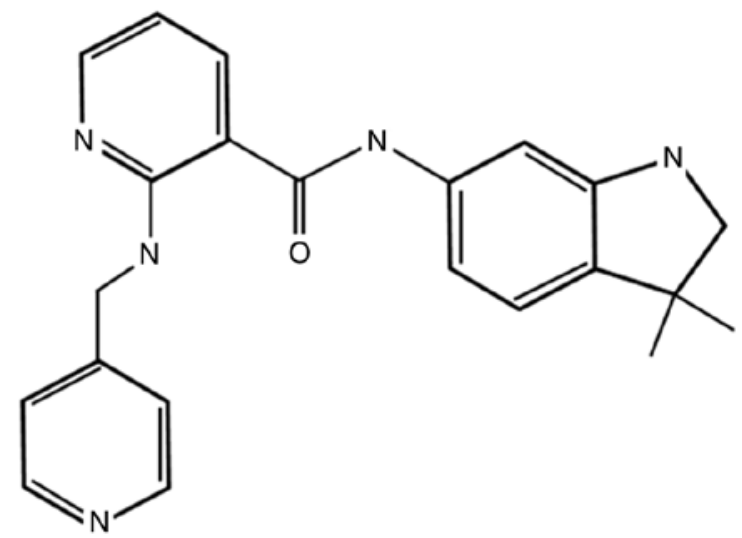

Figure 1. Structure of motesanib.

Table I. Sequences of primers

Gene

Sequences

VEGFR-1

F: TCATGAATGTTTCCCTGCAA

R: TTTGTTGCAGTGCTCACCTC

VEGFR-2

F: TGATCGGAAATGACACTGGA

R: CACGACTCCATGTTGGTCAC

VEGFR-3

F: GAGACAAGGACAGCGAGGAC

PDGFR- $\alpha$

R: CTGTGTCGTTGGCATGTACC

GAPDH

F: AGCTGATCCGTGCTAAGGAA

R: ATCGACCAAGTCCAGAATGG

F: TGCACCACCAACTGCTTAG

R: AGAGGCAGGGATGATGTTC

F, forward; R, reverse; VEGFR, VEGF corresponding receptors; PDGF, platelet-derived growth factor; PDGFR, PDGF receptor.

Cell cycle analysis. T24R 2 cells were cultured at 3x105/60 mm dish, grown for $24 \mathrm{~h}$, and then incubated with motesanib or cisplatin alone and combined for $48 \mathrm{~h}$. The cells were trypsinized, fixed in $70 \%$ ethanol, and stained with propidium iodide (PI; Sigma-Aldrich; Merck KGaA) solution for $30 \mathrm{~min}$ at $37^{\circ} \mathrm{C}$. The cell cycle distribution was determined on a FACSCalibur instrument (BD Biosciences, San Jose, CA, USA). The resultant data were analyzed with the BD CellQuest Pro software (BD Biosciences).

RNA extraction and real-time polymerase chain reaction $(P C R)$. Total RNA from T24R2 cells was extracted using the RNeasy Mini Kit (Qiagen, Inc., Valencia, CA, USA). cDNA was produced from $1 \mu \mathrm{g}$ RNA using the Omniscript RT kit (Qiagen, Inc.) according to the manufacturer's instructions. Real-time PCR was performed for target genes using the Power SYBR-Green PCR Master Mix (Applied Biosystems, Warrington, UK) with a 7500 Real-Time PCR system (Applied Biosystems; Thermo Fisher Scientific, Inc., Waltham, MA, USA). The specific primer sequences are presented in Table I. 
A

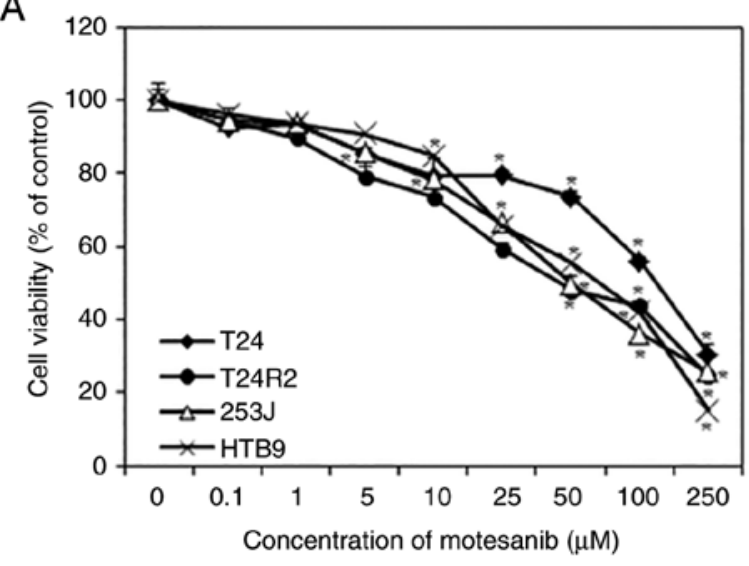

B

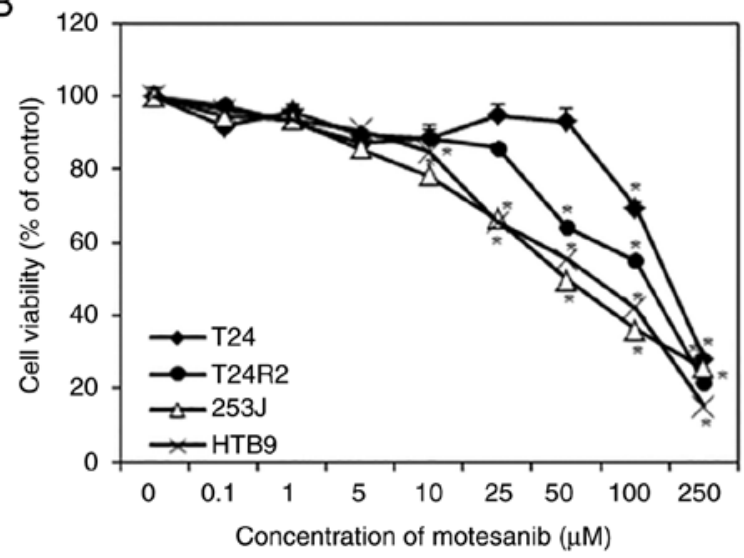

Figure 2. Effect of motesanib on human bladder cancer cells. The cells were treated with various concentrations of motesanib for (A) 48 and (B) 72 h. Cell viability was assessed by CCK- 8 assay. The data are represented as the mean \pm standard deviation (SD) of three independent experiments. ${ }^{*} \mathrm{P}<0.05$, statistically significant difference compared with the non-treated control. CCK-8, Cell Counting Kit-8.

Western blotting. Cells were lysed with radio immunoprecipitation assay buffer, consisting of $50 \mathrm{mM}$ Tris- $\mathrm{HCl}$ ( $\mathrm{pH} 8.0$ ), $150 \mathrm{mM}$ sodium chloride, $1.0 \% \mathrm{NP}-40,0.5 \%$ sodium deoxycholate, $0.1 \%$ sodium dodecyl sulfate, and $1 \mathrm{mM}$ phenylmethylsulfonyl fluoride. Protein concentrations from cell extracts were assessed using a bicinchoninic acid protein assay kit (Pierce; Thermo Fisher Scientific, Inc.). Equal amounts of total protein $(30 \mu \mathrm{g})$ were separated using sodium dodecyl sulfate-polyacrylamide gel electrophoresis (8-12\% SDS-PAGE) and transferred onto polyvinylidene fluoride membranes (EMD Millipore, Billerica, MA, USA). The membranes were blocked in 5\% (w/v) non-fat dry milk for $1 \mathrm{~h}$ at room temperature, and then incubated with primary antibodies (dilution 1:1,000) against poly(ADP-ribose) polymerase (PARP, cat. no. 9542); cleaved caspases-3 (cat. no. 9664), -8 (cat. no. 9496), and -9 (cat. no. 9505); cytochrome $c$ (cat. no. 4272); Bcl-2 (cat. no. 15071); Bad (cat. no. 9268); cyclin E1 (cat. no. 4129); phosphoinositide 3-kinase (PI3K; cat. no. 4257); phospho-PI3 kinase p85 (Tyr458)/p55 (Tyr199; cat.no.4228); protein kinase B (Akt, cat.no.4685); phospho-Akt (Ser473; cat. no. 4060); extracellular signal-regulated kinases (Erk; cat. no. 4695); phosphorylated-p44/42 MAPK (Erk1/2) (Thr202/Tyr204; cat. no. 4376); VEGF (cat. no. 2445); VEGFR-1 (cat. no. 2893); VEGFR-2 (cat. no. 2479) (Cell Signaling Technology, Inc., Beverly, MA, USA); and VEGFR-3 (cat. no. sc-28297) (Santa Cruz Biotechnology Inc., Santa Cruz, CA, USA) at $4^{\circ} \mathrm{C}$ overnight. After incubation with horseradish peroxidase (HRP)-conjugated anti-mouse IgG (dilution 1:10,000; cat. no. sc-516102) or anti-rabbit IgG (dilution 1:5,000; cat no. sc-2004) for $1 \mathrm{~h}$, protein expression was detected with the Enhanced Chemiluminescence Western Blot substrate kit (Pierce; Thermo Fisher Scientific, Inc.). The blots were analyzed using ImageJ $1.48 \mathrm{v}$ software $(\mathrm{NIH}$; National Institutes of Health, Bethesda, MD, USA).

Statistical analysis. The data are presented as the mean \pm standard deviation of three independent experiments. Statistical analysis was performed using SPSS statistical software package (IBM SPSS statistics 20; IBM Corp., Armonk, NY, USA). $\mathrm{P}<0.05$ was considered to indicate a statistically significant difference as determined by ANOVA followed by Tukey's multiple-range test.

\section{Results}

Combination treatment of motesanib and cisplatin suppresses proliferation of human bladder cancer cells. Bladder cancer cell lines were exposed to motesanib $(0,0.1,1,5,10,25,50$, 100 and $250 \mu \mathrm{M}$ ), with cell viability assessed by CCK-8 assay. As revealed in Fig. 2, treatment with motesanib for 48 and $72 \mathrm{~h}$ inhibited the proliferation of bladder cancer cells in a dose-dependent manner when compared with that of non-treated cells (control). Highly sensitive cell line T24R2 was selected at $48 \mathrm{~h}$ for further investigation. Compared with the individual drug, the drug combination of $50 \mu \mathrm{M}$ motesanib with $2.5 \mu \mathrm{g} / \mathrm{ml}$ cisplatin induced significant inhibition of cell proliferation (Fig. 3).

To evaluate the antiproliferative effect of motesanib combined with cisplatin on T24R 2 cells, a clonogenic assay was performed. The colony-forming ability of T24R 2 cells was significantly inhibited by 56.9 and $28.3 \%$ when treated with $50 \mu \mathrm{M}$ motesanib or $2.5 \mu \mathrm{g} / \mathrm{ml}$ cisplatin only, respectively, in comparison with that of the non-treated control (Fig. 4). Particularly, the combination of $50 \mu \mathrm{M}$ motesanib and $2.5 \mu \mathrm{g} / \mathrm{ml}$ cisplatin demonstrated improved suppression of clonogenic formation, compared to motesanib or cisplatin alone. These data indicated that motesanib and cisplatin treatment could synergistically suppress the proliferation of bladder cancer cells.

Cell cycle alteration in bladder cancer cells caused by treatment with motesanib and cisplatin. Flow cytomety was performed to assess changes in the cell cycle and apoptosis in bladder cancer cells. As revealed in Fig. 5, the combined treatment of $50 \mu \mathrm{M}$ motesanib and $2.5 \mu \mathrm{g} / \mathrm{ml}$ cisplatin significantly increased the sub-G1 cell percentage. These results revealed that the combination treatment increased the sub-G1 population, corresponding to apoptotic cells, in T24R2 bladder cancer cells. In addition, cisplatin alone and combination treatment primarily increased the S-phase cell percentage on compared 


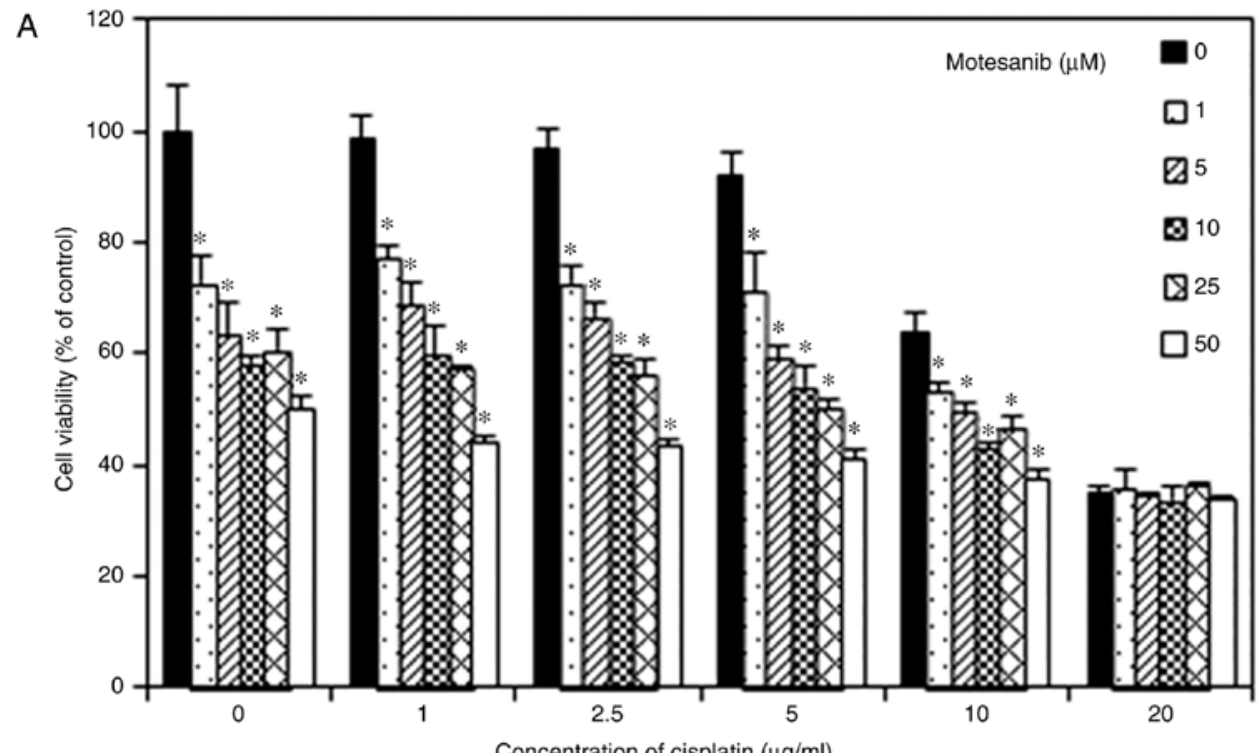

B 9

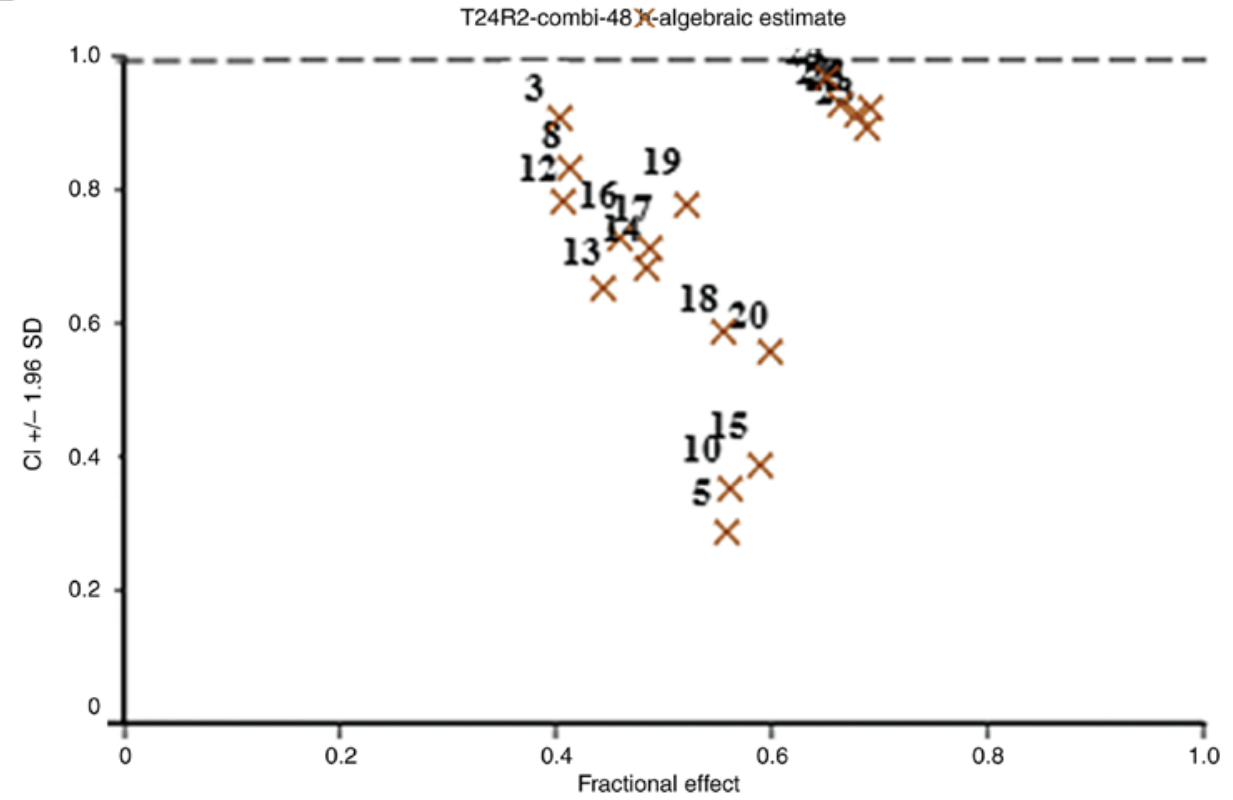

Figure 3. Effect of combination treatment of motesanib and cisplatin on T24R2 cell viability. (A) The cells were co-treated with motesanib $(0,1,5,10,25$ and $50 \mu \mathrm{M})$ and cisplatin $(0,1,2.5,5,10$ and $20 \mu \mathrm{g} / \mathrm{ml})$ for $48 \mathrm{~h}$, and viability was evaluated by CCK- 8 assay. (B) Combination index of motesanib and cisplatin was $<1.0$, revealing synergism. The data are represented as the mean \pm standard deviation (SD) of three independent experiments. "P $<0.05$, statistically significant difference compared with the non-treated control. CCK-8, Cell Counting Kit-8.

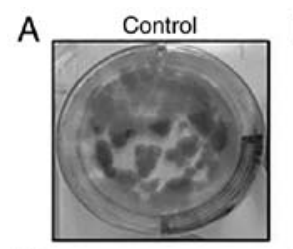

C

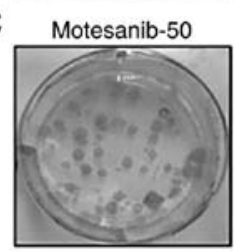

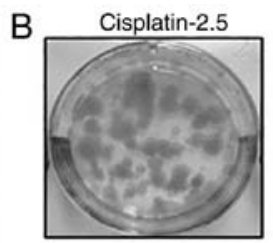

D Cis-2.5+mot-50

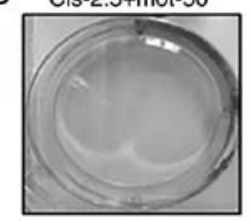

E

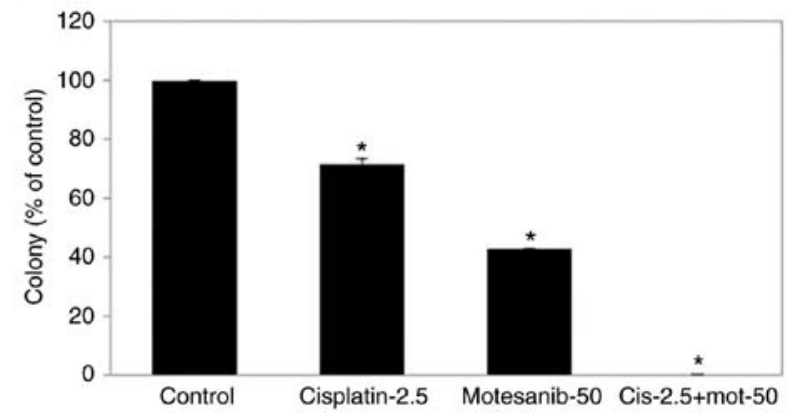

Figure 4. Effect of combination treatment of motesanib and cisplatin in T24R 2 cells determined by clonogenic assay. The cells were treated with $50 \mu \mathrm{M}$ motesanib and $2.5 \mu \mathrm{g} / \mathrm{ml}$ cisplatin (A-D) Image of T24R 2 cells. (E) The number of colonies in T24R2 cells. The data are represented as the mean \pm standard deviation (SD) of three independent experiments. ${ }^{*} \mathrm{P}<0.05$, statistically significant difference compared with the non-treated control. 

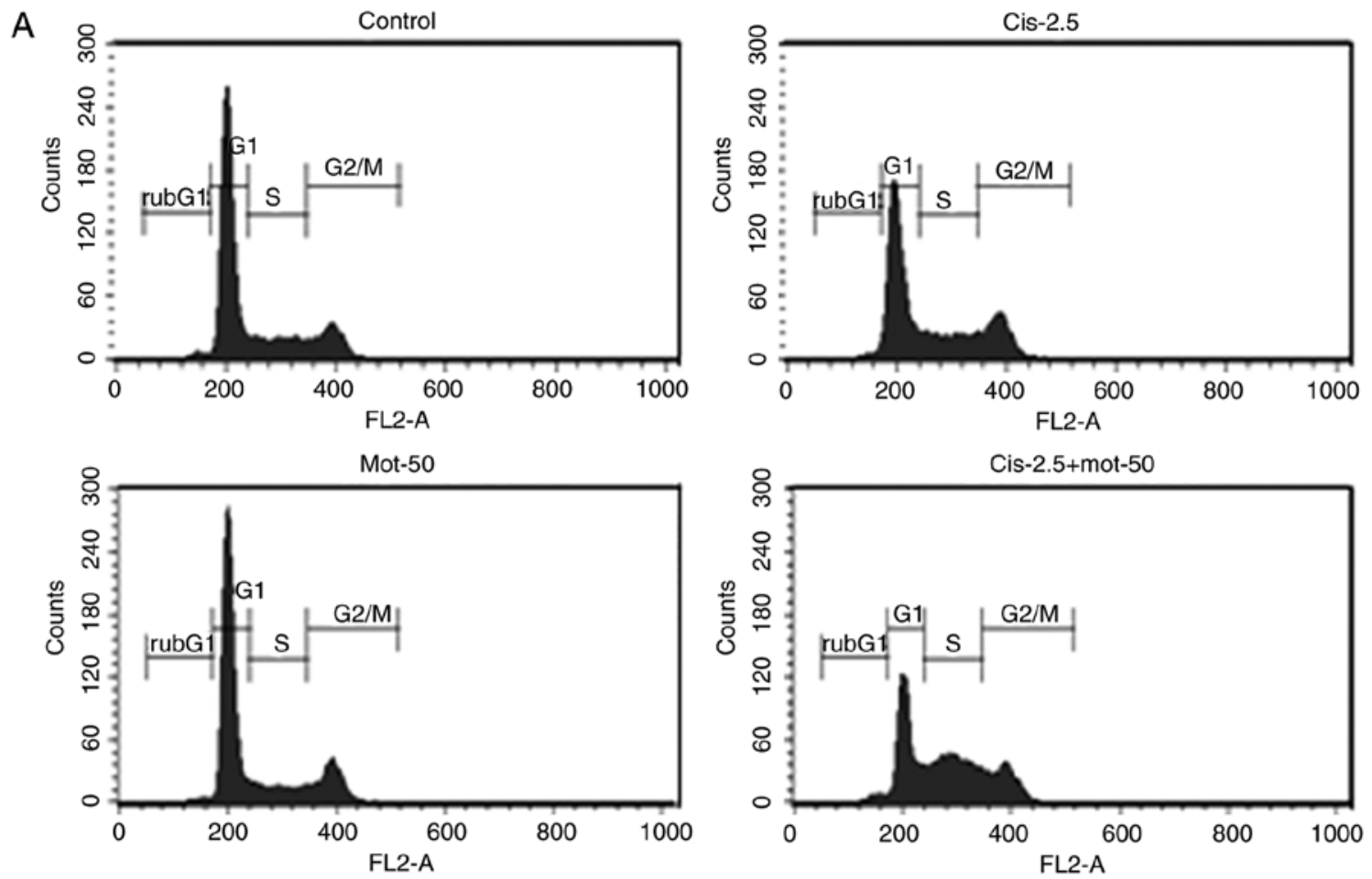

B

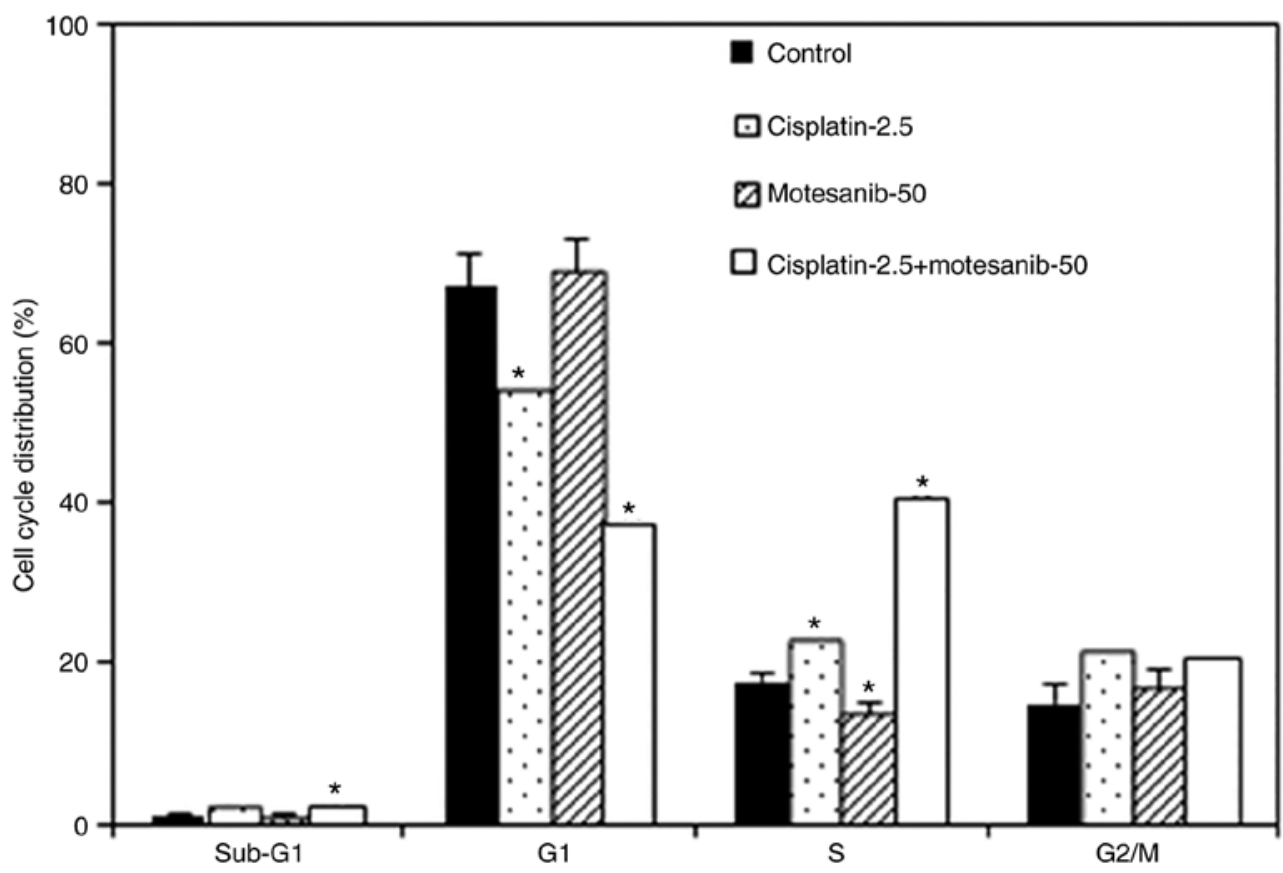

Figure 5. Effect of combination treatment of motesanib and cisplatin on cell cycle progression. The cells were co-treated with $50 \mu \mathrm{M}$ motesanib and $2.5 \mu \mathrm{g} / \mathrm{ml}$ cisplatin for $48 \mathrm{~h}$. Cellular DNA was stained with PI and flow cytometric analysis was performed to analyze the cell cycle distribution. (A) Flow cytometric DNA content histogram of T24R2 cells. (B) Quantitative measurements of cycle alterations in T24R2. The data are represented as the mean \pm standard deviation (SD) of three independent experiments. ${ }^{*} \mathrm{P}<0.05$, statistically significant difference compared with the non-treated control. PI, propidium iodide.

with the non-treated control. Thus it was demonstrated that the combined treatment of motesanib and cisplatin strongly altered the cell cycle progression of the bladder cancer cell line.

Effect of combined treatment of motesanib and cisplatin on VEGFR. To examine whether VEGFR and PDGFR are affected by the combined treatment of motesanib and cisplatin, VEGFR and PDGFR mRNA expression was determined by real-time PCR. The combined treatment of motesanib and cisplatin significantly reduced the mRNA expression levels of VEGFR-1, -3 and PDGFR- $\alpha$ compared to those of the non-treated control (Fig. 6). VEGFR-2 mRNA expression was also decreased by motesanib alone and combination treatment of motesanib and cisplatin. However, the change was not significant. Moreover, VEGFR-1, -2, and -3 protein levels were also significantly reduced by combination treatment of motesanib and cisplatin (Fig. 7). 
A

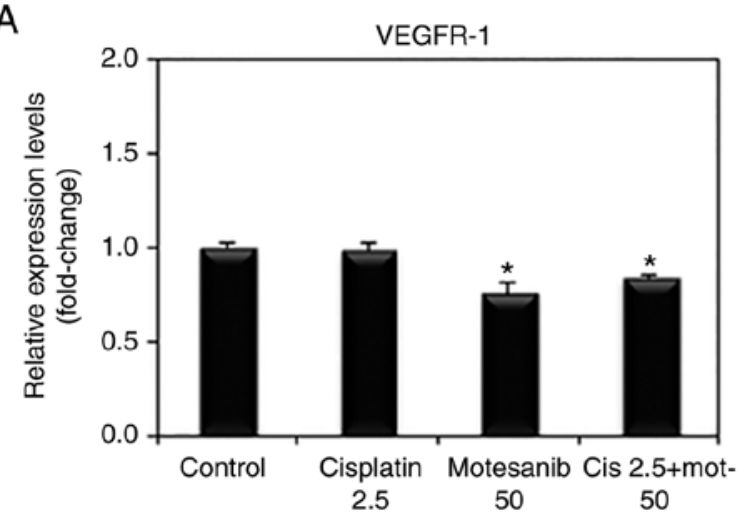

C

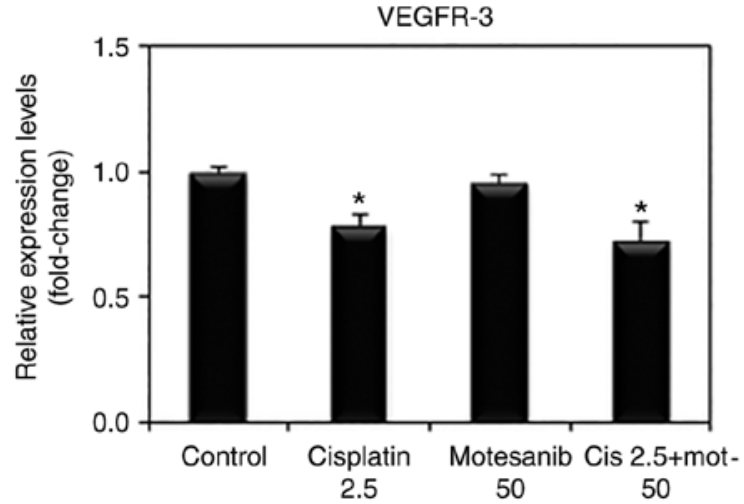

B

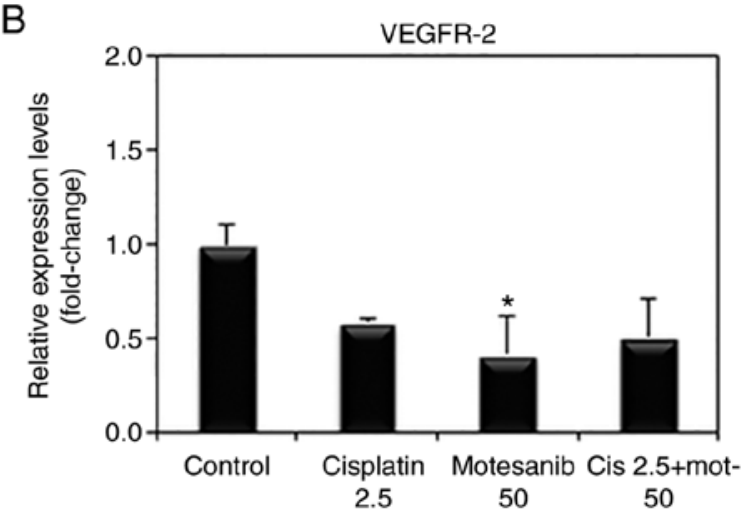

D

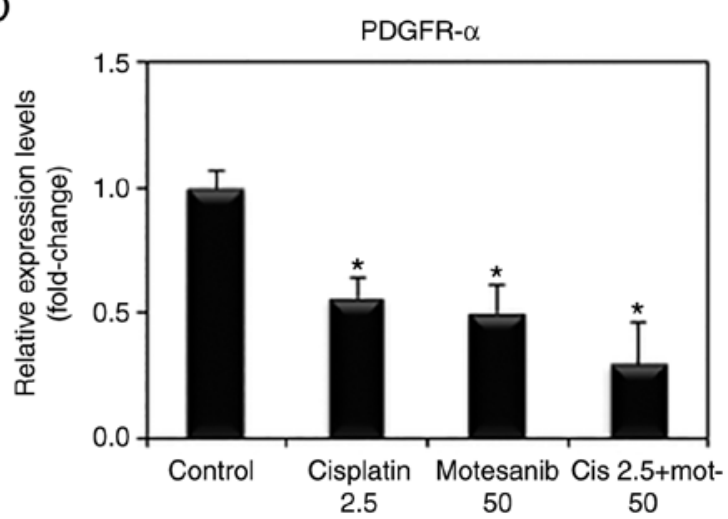

Figure 6. Effect of the combination treatment of motesanib and cisplatin on mRNA expression of VEGFR and PDGFR in T24R2 cells. (A-C) VEGFR-1-3. (D) PDGFR- $\alpha$. The cells were co-treated with $50 \mu \mathrm{M}$ motesanib and $2.5 \mu \mathrm{g} / \mathrm{ml}$ cisplatin for $48 \mathrm{~h}$, and the mRNA expression was assessed by real-time PCR. The data are represented as the mean \pm standard deviation (SD) of three independent experiments. ${ }^{*} \mathrm{P}<0.05$, statistically significant difference compared with the non-treated control. VEGF, vascular endothelial growth factor; VEGFR, VEGF corresponding receptors; PDGF, platelet-derived growth factor; PDGFR, PDGF receptor.

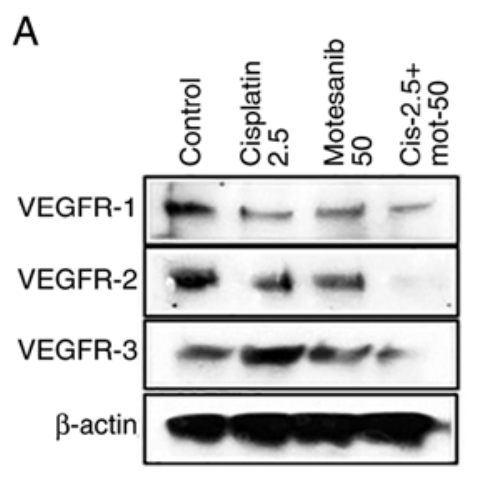

B

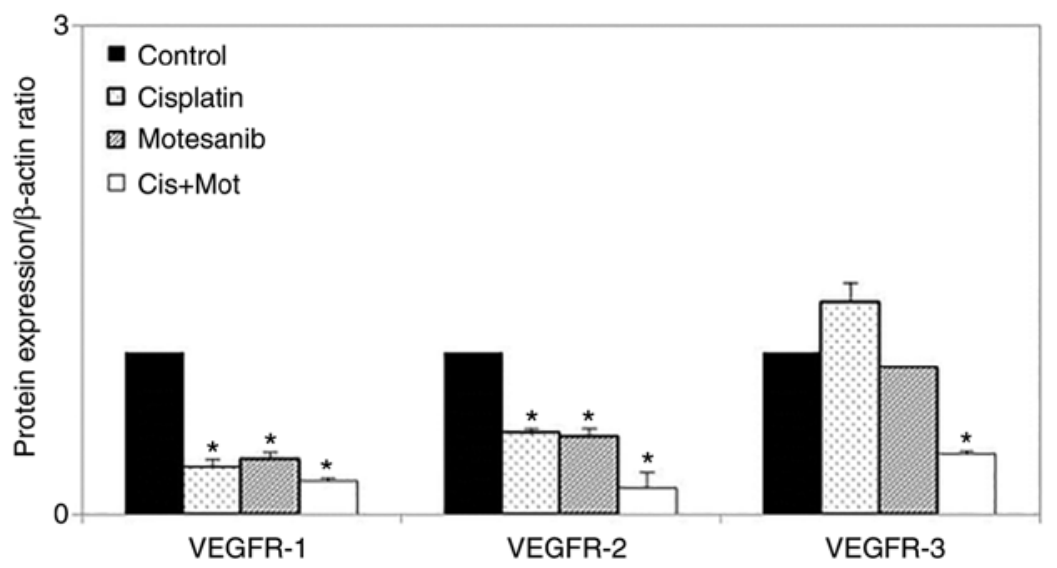

Figure 7. Effect of the combination treatment of motesanib and cisplatin on the protein expression of VEGFR in T24R2 cells. (A) The cells were co-treated with $50 \mu \mathrm{M}$ motesanib and $2.5 \mu \mathrm{g} / \mathrm{ml}$ cisplatin for $48 \mathrm{~h}$, and the protein expression was analyzed by western blotting. Equal amounts of total protein were loaded onto the gels for SDS-PAGE. (B) Densitometric assessment for each protein. The data are represented as the mean \pm standard deviation (SD) of three independent experiments. "P<0.05, statistically significant difference compared with the non-treated control. VEGF, vascular endothelial growth factor; VEGFR, VEGF corresponding receptors; SDS-PAGE, sodium dodecyl sulfate-polyacrylamide gel electrophoresis.

Change in the expression of proteins regulating apoptosis and the cell cycle in bladder cancer cells caused by treatment with motesanib and cisplatin. To confirm the antitumor effect of the combined treatment of motesanib and cisplatin, western blot analysis was performed. The expression levels of caspases-3, -8, and -9; fragmented PARP; and cytochrome $c$ were markedly enhanced by the combined treatment of motesanib and cisplatin in T24R2 cells (Fig. 8). Furthermore, the expression of the anti-apoptotic protein $\mathrm{Bcl}-2$ was markedly reduced by combined treatment in T24R 2 cells, whereas the 
A

B
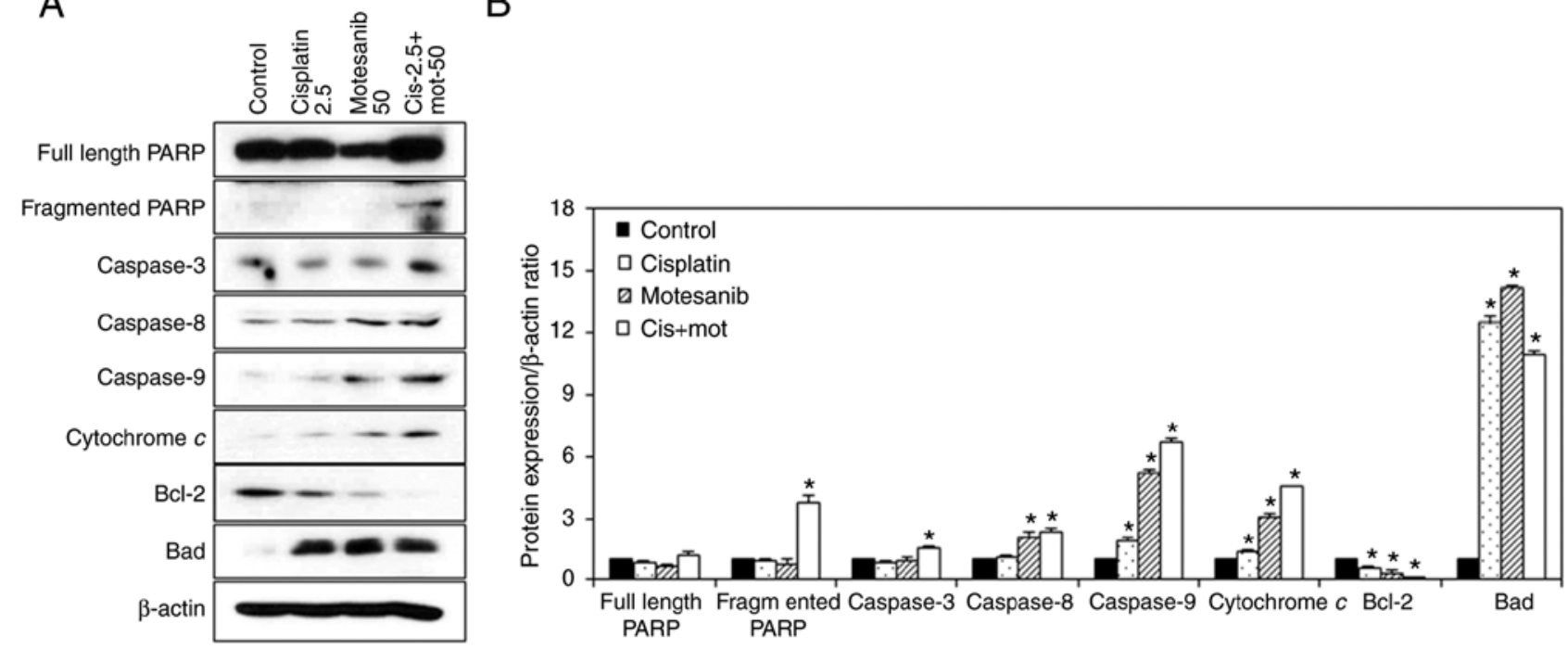

Figure 8. Effect of the combination treatment of motesanib and cisplatin on apoptosis-related protein expression in T24R2 cells. (A) The cells were co-treated with $50 \mu \mathrm{M}$ motesanib and $2.5 \mu \mathrm{g} / \mathrm{ml}$ cisplatin for $48 \mathrm{~h}$, and the protein expression was analyzed by western blotting. Equal amounts of total protein were loaded onto the gels for SDS-PAGE. (B) Densitometric assessment for each protein. The data are represented as the mean \pm standard deviation (SD) of three independent experiments. "P<0.05, statistically significant difference compared with the non-treated control. SDS-PAGE, sodium dodecyl sulfate-polyacrylamide gel electrophoresis.
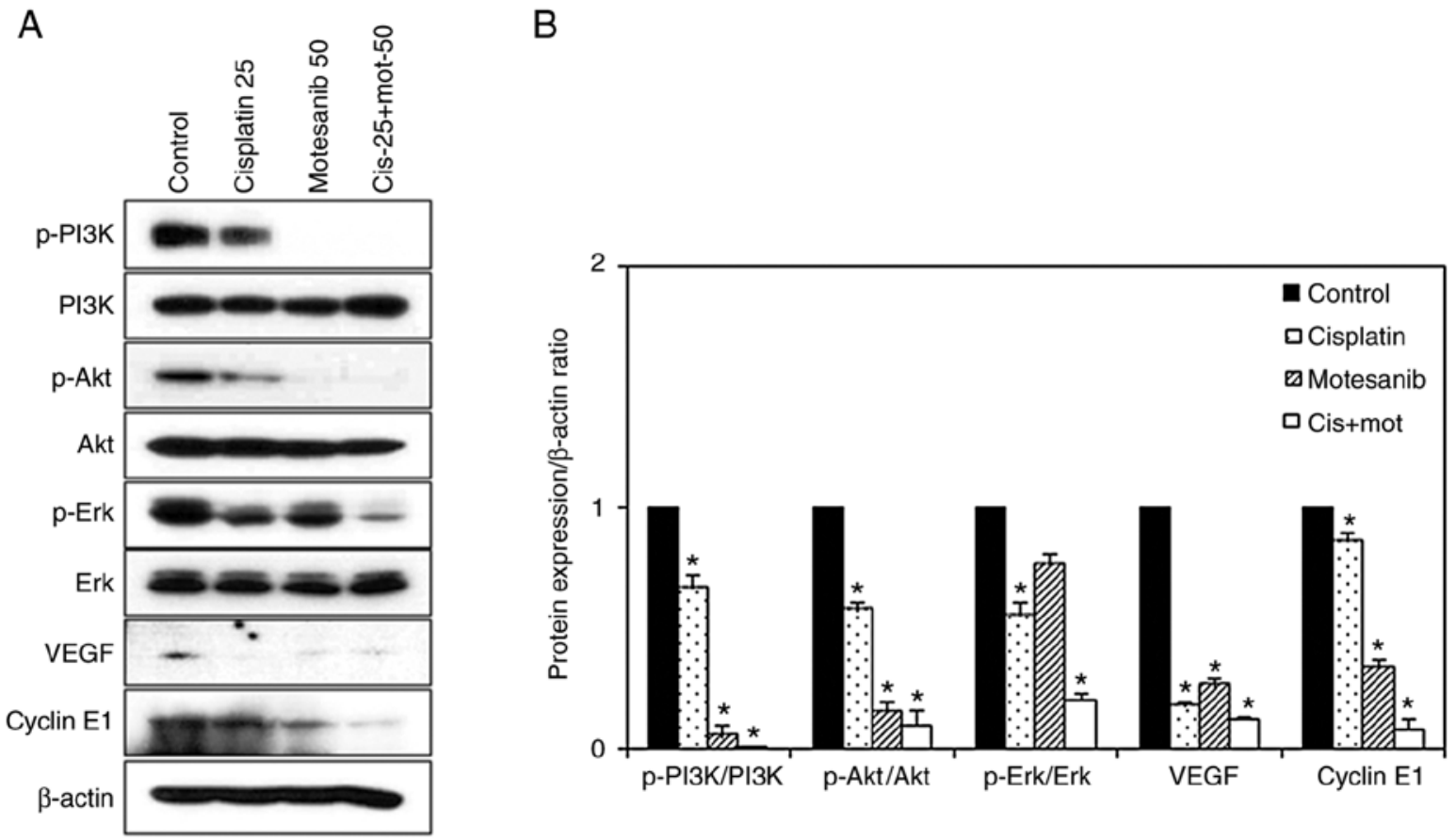

Figure 9. Effect of the combination treatment of motesanib and cisplatin on cell survival-related protein expression in T24R2 cells. (A) The cells were co-treated with $50 \mu \mathrm{M}$ motesanib and $2.5 \mu \mathrm{g} / \mathrm{ml}$ cisplatin for $48 \mathrm{~h}$, and the protein expression was analyzed by western blotting. Equal amounts of total protein were loaded onto the gels for SDS-PAGE. (B) Densitometric assessment for each protein. The data are represented as the mean \pm standard deviation (SD) of three independent experiments. "P $<0.05$, statistically significant difference compared with the non-treated control. SDS-PAGE, sodium dodecyl sulfate-polyacrylamide gel electrophoresis.

expression of the pro-apoptotic protein Bad was increased. In addition, the expression of cyclins as an index of S-phase arrest was assessed (21). The combined treatment of motesanib and cisplatin markedly decreased cyclin E1 (Fig. 9). Phosphorylation of PI3K, Akt, and Erk were significantly suppressed by the combined treatment in the bladder cancer cells. Total PI3K, Akt, and Erk did not exhibit any significant changes. In addition, both motesanib and cisplatin individually resulted in lower levels of VEGF compared to those of the non-treated control. These results indicated that the combined treatment of motesanib and cisplatin inhibited the growth of bladder cancer cells via an apoptosis-related mechanism, and disrupted cell survival by inhibiting the PI3K/Akt signaling pathway. 


\section{Discussion}

Angiogenesis plays a critical role in tumor growth and metastasis and involves several growth factors and their receptors, particularly VEGF and VEGFRs (22). Therefore, multiple agents that inhibit VEGFR and PDGFR have proved to be beneficial in cancer treatment (23). Recently, new targeted agents, i.e., monoclonal antibodies, fusion proteins and small-molecule inhibitors, have been developed and are being used clinically (24). In our study, we determined the antitumor effects of motesanib, a small-molecule multikinase inhibitor, alone or in combination with cisplatin by evaluating cell proliferation, colony formation, cell cycle, and by expression of mRNA and proteins associated with angiogenesis, apoptosis, and cell survival in human bladder cancer cells.

VEGF is the primary proangiogenic mediator. VEGF mRNA and protein are overexpressed in advanced bladder cancer compared with those in normal bladder epithelium (25). Wang et al reported that inhibition of VEGF expression reduced the development of metastasis (26). Blocking VEGF or its receptors reduced tumor growth in animal models $(27,28)$. VEGF acts on two principal tyrosine kinase receptors, VEGFR-1 and VEGFR-2, both of which are overexpressed in most vascular tumors and therefore are attractive therapeutic targets (25). As anticipated, motesanib significantly reduced the mRNA expression of VEGFR-1, VEGFR-2, and PDGFR- $\alpha$ and the protein expression of VEGF, VEGFR-1 and VEGFR-2. Furthermore, the combined treatment of motesanib and cisplatin significantly decreased the mRNA expression of VEGFR-1, VEGFR-3 and PDGFR- $\alpha$ and the protein expression of VEGF, VEGFR-1, VEGFR-2 and VEGFR-3.

The targeting and induction of apoptosis are particularly interesting strategies in cancer therapy, as the occurrence of apoptosis shifts the treatment effect from a cytostatic to cytotoxic state (29). Cisplatin primarily induces cell death by apoptosis, and a defect in apoptotic signaling could confer cisplatin resistance (5). To better understand the effect of combination treatment on apoptosis, a western blot analysis was performed. Treatment with a combination of $50 \mu \mathrm{M}$ motesanib and $2.5 \mu \mathrm{g} / \mathrm{ml}$ cisplatin led to a synergistic increase in the expression of apoptosis-related proteins (fragmented PARP, cleaved caspase-3, -8, and -9 and cytochrome $c$ ). Furthermore, combination treatment of motesanib and cisplatin markedly reduced the expression of the anti-apoptotic protein Bcl-2, whereas Bad expression was increased, confirming the promotion of apoptosis. Since Bcl-2 overexpression is responsible for cisplatin resistance (30), combination treatment with motesanib could have resulted in comprehensive downregulation of anti-apoptotic proteins in T24R2 cells, lowering the hurdle to apoptosis induction. Treatment with motesanib alone or motesanib plus cisplatin revealed significant reduction in cell proliferation and colony formation compared with those of non-treated control cells. The effect on cell proliferation reduction observed with the combination of motesanib and cisplatin may be due, at least in part, to the induction of apoptosis, which may increase the antitumor activity of cisplatin (9). Consistent with our findings, Kaya et al, reported that the main mechanism of action of motesanib is the inhibition of tumor angiogenesis, but it also has antiproliferative and apoptotic effects on HT29 colorectal cancer cells (24).

The PI3K signaling pathway is involved in the regulation of cancer cell growth, motility, survival and metabolism (31). Several studies have demonstrated that the PI3K signaling pathway is excessively activated in muscle-invasive or metastatic bladder cancer (32). Akt is a family of serine/threonine kinases that acts downstream of PI3K and plays a critical role in cell survival and growth $(5,28)$. Akt activity is dependent on phosphorylation at two sites: T308 and S473 (33). Phosphorylated Akt can inhibit apoptosis resulting in the degradation of the $\mathrm{p} 53$ protein, and inactivating pro-apoptotic proteins Bad, Bax or caspase-3 (34). In our results, PI3K/Akt phosphorylation levels were markedly decreased by combination treatment of motesanib and cisplatin. Therefore, motesanib and cisplatin synergistically suppressed T24R2 bladder cancer cell growth through the promotion of apoptosis and reduction of survival related proteins. Collectively, these results emphasized the superior cisplatin sensitizing effect of motesanib in cisplatin-resistant bladder cancer cells.

In conclusion, the combined treatment of motesanib and cisplatin can actively induce tumor cell growth inhibition, cell cycle arrest at the $\mathrm{S}$ phase, reduced VEGFR and PDGFR mRNA expression and enhanced apoptosis with increasing levels of cleaved PARP, caspases, and Bad in cisplatin-resistant human bladder cancer cells. Our results indicated that motesanib is a promising agent for the treatment of bladder cancer.

\section{Acknowledgements}

Not applicable.

\section{Funding}

The present study was supported by the grant nos. 13-2015-014 and 03-2010-013 from the Seoul National University Bundang Hospital Research Fund.

\section{Availability of data and materials}

The datasets used during the present study are available from the corresponding author upon reasonable request.

\section{Authors' contributions}

SL designed the study, assembled and interpreted the data, wrote the manuscript and managed the project. JNH performed the experiments, analyzed the results and wrote the manuscript. SSB and SEL were responsible for the collection and data analysis and revised the manuscript. JIY analyzed the data and approved the final version of the manuscript. All authors read and approved the final manuscript and agree to be accountable for all aspects of the research in ensuring that questions related to the accuracy or integrity of any part of the work are appropriately investigated and resolved.

\section{Ethics approval and consent to participate}

Not applicable. 


\section{Patient consent for publication}

Not applicable.

\section{Competing interests}

The authors declare that they have no competing interests.

\section{References}

1. Antoni S, Ferlay J, Soerjomataram I, Znaor A, Jemal A and Bray F: Bladder cancer incidence and motality: A Global overview and recent trends. Eur Urol 71: 96-108, 2017.

2. Kamat AM, Hahn NM, Efstathiou JA, Lerner SP, Malmström PU, Choi W, Guo CC, Lotan Y and Kassouf W: Bladder cancer. Lancet 388: 2796-2810, 2016.

3. Godwin JL, Hoffman-Censits J and Plimack E: Recent developments in the treatment of advanced bladder cancer. Urol Oncol 36: 109-114, 2018.

4. McHugh LA, Kriajevska M, Mellon JK and Griffiths TR: Combined treatment of bladder cancer cell lines with lapatinib and varying chemotherapy regimens-evidence of schedule-dependent synergy. Urology 69: 390-394, 2007.

5. Dasari S and Tchounwou PB: Cisplatin in cancer therapy: Molecular mechanisms of action. Eur J Pharmacol 740: 364-378, 2014.

6. Zhao Y and Adjei AA: Targeting angiogenesis in cancer therapy: Moving beyond vascular endothelial growth factor. Oncologist 20: 660-673, 2015.

7. Fus ŁP and Górnicka B: Role of angiogenesis in urothelial bladder carcinoma. Cent Eurpean J Urol 69: 258-263, 2016.

8. Bellmunt J, Hussain M and Dinney CP: Novel approaches with targeted therapies in bladder cancer therapy of bladder cancer by blockade of the epidermal growth factor receptor family. Crit Rev Oncol Hematol 46 (Suppl 46): S85-S104, 2003.

9. Coxon A, Bush T, Saffran D, Kaufman S, Belmontes B, Rex K Hughes P, Caenepeel S, Rottman JB, Tasker A, et al: Broad antitumor activity in breast cancer xenografts by motesanib, a highly selective, oral inhibitor of vascular endothelial growth factor platelet-derived growth factor, and Kit receptors. Clin Cancer Res 15: 110-118, 2009.

10. Li Y, Yang X, Su LJ and Flaig TW: Pazopanib synergizes with docetaxel in the treatment of bladder cancer cells. Urology 78 233, e7-233.e13, 2011

11. Black PC, Agarwal PK and Dinney CP: Targeted therapies in bladder cancer-an update. Urol Oncol 25: 433-438, 2007.

12. Jordan EJ and Iyer G: Targeted therapy in advanced bladder cancer: What have we learned? Urol Clin North Am 42: 253-262, 2015.

13. Polverino A, Coxon A, Starnes C, Diaz Z, DeMelfi T, Wang L, Bready J, Estrada J, Cattley R, Kaufman S, et al: AMG 706, an oral, multikinase inhibitor that selectively targets vascular endothelial growth factor, platelet-derived growth factor, and kit receptors, potently inhibits angiogenesis and induces regression in tumor xenografts. Cancer Res 66: 8715-8721, 2006.

14. Rosen LS, Kurzrock R, Mulay M, Van Vugt A, Purdom M, Ng C, Silverman J, Koutsoukos A, Sun YN, Bass MB, et al: Safety, pharmacokinetics, and efficacy of AMG 706, an oral multikinase inhibitor, in patients with advanced solid tumors. J Clin Oncol 25: 2369-2376, 2007.

15. Coxon A, Bready J, Kaufman S, Estrada J, Osgood T, Canon J, Wang L, Radinsky R, Kendall R, Hughes P, et al: Anti-tumor activity of motesanib in a medullary thyroid cancer model. J Endocrinol Invest 35: 181-190, 2012

16. Coxon A, Ziegler B, Kaufman S, Xu M, Wang H, Weishuhn D, Schmidt J, Sweet H, Starnes C, Saffran D and Polverino A Antitumor activity of motesanib alone and in combination with cisplatin or docetaxel in multiple human non-small-cell lung cancer xenograft models. Mol Cancer 11: 70, 2012.
17. Tebbutt N, Kotasek D, Burris HA, Schwartzberg LS, Hurwitz H, Stephenson J, Warner DJ, Chen L, Hsu CP and Goldstein D: Motesanib with or without panitumumab plus FOLFIRI or FOLFOX for the treatment of metastatic colorectal cancer. Cancer Chemother Pharmacol 75: 993-1004, 2015.

18. Lu JF, Claret L, Sutjandra L, Kuchimanchi M, Melara R, Bruno R and Sun YN: Population pharmacokinetic/pharmacodynamic modeling for the time course of tumor shrinkage by motesanib in thyroid cancer patients. Cancer Chemother Pharmacol 66: 1151-1158, 2010.

19. Schilder RJ, Sill MW, Lankes HA, Gold MA, Mannel RS, Modesitt SC, Hanjani P, Bonebrake AJ, Sood AK, Godwin AK, et al: A phase II evaluation of motesanib (AMG 706) in the treatment of persistent or recurrent ovarian, fallopian tube and primary peritoneal carcinomas: A Gynecologic Oncology Group study. Gynecol Oncol 129: 86-91, 2013.

20. Byun SS, Kim SW, Choi H, Lee C and Lee E: Augmentation of cisplatin sensitivity in cisplatin-resistant human bladder cancer cells by modulating glutathione concentrations and glutathione-related enzyme activities. BJU Int 95: 1086-1090, 2005.

21. Yeo EJ, Ryu JH, Chun YS, Cho YS, Jang IJ, Cho H, Kim J, Kim MS and Park JW: YC-1 induces $S$ cell cycle arrest and apoptosis by activating checkpoint kinases. Cancer Res 66: 6345-6352, 2006

22. Carmeliet P: VEGF as a key mediator of angiogenesis in cancer. Oncology 69 (Suppl 3): S4-S10, 2005.

23. Appelmann I, Liersch R, Kessler T, Mesters RM and Berdel WE: Angiogenesis inhibition in cancer therapy: Platelet-derived growth factor (PDGF) and vascular endothelial growth factor (VEGF) and their receptors: Biological functions and role in malignancy. Recent Results Cancer Res 180: 51-81, 2010.

24. Kaya TT, Altun A, Turgut NH, Ataseven H and Koyluoglu G: Effects of a multikinase inhibitor motesanib (AMG 706) alone and combined with the selective DuP-697 COX-2 inhibitor on colorectal cancer cells. Asian Pac J Cancer Prev 17: 1103-1110, 2016.

25. Elfiky AA and Rosenberg JE: Targeting angiogenesis in bladder cancer. Curr Oncol Rep 11: 244-249, 2009.

26. Wang F, Li HM, Wang HP, Ma JL, Chen XF, Wei F, Yi MY and Huang Q: siRNA-mediated knockdown of VEGF-A, VEGF-C and VEGFR-3 suppresses the growth and metastasis of mouse bladder carcinoma in vivo. Exp Ther Med 1: 899-904, 2010.

27. Wu CL, Ping SY, Yu CP and Yu DS: Tyrosine kinase receptor inhibitor-targeted combined chemotherapy for metastatic bladder cancer. Kaohsiung J Med Sci 28: 194-203, 2012.

28. Van Kessel KE, Zuiverloon TC, Alberts AR, Boormans JL and Zwarthoff EC: Targeted therapies in bladder cancer: An overview of in vivo research. Nat Rev Urol 12: 681-694, 2015.

29. Madka V, Zhang Y, Li Q, Mohammed A, Sindhwani P, Lightfoot S, Wu XR, Kopelovich L and Rao CV: P53-stabilizing agent $\mathrm{CP}-31398$ prevents growth and invasion of urothelial cancer of the bladder in transgenic UPII-SV40T mice. Neoplasia 15: 966-974, 2013

30. Kim SH, Ho JN, Jin H, Lee SC, Lee SE, Hong SK, Lee JW, Lee ES and Byun SS: Upregulated expression of BCL2, MCM7, and CCNE1 indicate cisplatin-resistance in the set of two human bladder cancer cell lines: T24 cisplatin sensitive and T24R2 cisplatin resistant bladder cancer cell lines. Investig Clin Urol 57: 63-72, 2016.

31. Bartholomeusz $\mathrm{C}$ and Gonzalez-Angulo AM: Targeting the PI3K signaling pathway in cancer therapy. Expert Opin Ther Targets 16: 121-130, 2012.

32. Sathe A and Nawroth R: Targeting the PI3K/AKT/mTOR pathway in bladder cancer. methods Mol Biol 1655: 335-350, 2018.

33. Dienstmann R, Rodon J, Serra V and Tabernero J: Picking the point of inhibition: A comparative review of PI3K/AKT/mTOR pathway inhibitors. Mol Cancer Ther 13: 1021-1031, 2014.

34. Fayard ETL, Baudry A and Hemmings BA: Protein kinase B/Akt at a glance. J Cell Sci 118: 5675-5678, 2005. 